\title{
Exploring Language Learning Style Preferences of the ELT Graduate Students
}

ISSN: 2311-8636 (Print)

ISSN: 2312-2021 (Online)

DOI prefix: 10.18034

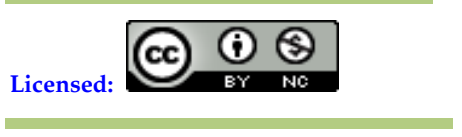

Source of Support: Nil

No Conflict of Interest: Declared

${ }^{*}$ Email for correspondence:

rumana.raf@gmail.com

more or less aware of their own learning styles and the way they learn better. It was found out from the study that majority of the students preferred the auditory style of learning while individual style is the least preferred. The study also brings students' opinions regarding learning styles in the field of learning ESL (English as a Second Language) or EFL (English as a Foreign Language) to light. The paper then discusses the implications of the findings and offers some recommendations regarding the need to identify students' learning styles in Bangladeshi classroom.

Key Words: Learning Styles, Learning Style Models, ESL/EFL Learning Style Preferences, Awareness of Individual Styles

\section{INTRODUCTION}

Learning styles (LS) are different "individual ways of taking in, organizing and processing information" (Felder, 1995). In the context of learning English as a second (ESL) or foreign language (EFL), having knowledge of one's own learning style plays a vital role since it determines the success of how well a student learns a language. Besides, there is often a mismatch between teacher's teaching of English and student's experience of learning it due to the misconception that there is one 'right' way to learn a language (Herod, 2000). This is a typical picture of the most schools and colleges in Bangladesh where English is taught as a foreign language (EFL). Studies (Islam, 2013; Huda, 2013) done on the Bangladeshi EFL learners' learning style show that teachers are relatively less aware of learners' choices when it comes to the teaching in the actual classroom. It is therefore, necessary for both the teachers and the students to have the knowledge of their teaching and learning preferences. Moreover, it "may have wide-ranging implications in the areas of curriculum design, materials development, student orientation, and teacher training" (Reid, 1987). Keeping that in mind, the present study tries to explore the learning style preferences of the ELT (English Language Teaching) graduate students of the English department of the 
University of Dhaka who are the pre-service teachers and learnt English as a second language (ESL) in their B.A and M.A (Applied Linguistics and ELT) program and will be teaching in actual classroom in the future soon. The study, hence, aims to answer the following research questions:

a. To what extent do the students follow language learning styles?

b. What are the most preferred as well as least preferred language learning styles of the students?

The results of this study, hopefully, will make the pre-service teachers aware of and recognize their own learning styles. It will help them adopt a student-centered pedagogy when they are in a classroom setting. Moreover, the results of the study will help the teachers to a great extent to realize their learners' individual differences and potential in learning English. Also, this will assist them adapting a variety of teaching approaches in order to make the learning of English easier, more flexible and interesting.

\section{LITERATURE REVIEW}

Researches done by Kolb (1984), Reid (1987, 1995), Oxford and Ehrman (1993), Felder (1995) and others in exploring learners' learning style preferences have significant implications in the field of ESL and EFL.

\section{Defining Learning Styles}

The term "learning styles" has been defined differently by different researchers. According to Cornett (1983) as cited in Ahmed (2013), learning styles are the "overall patterns that give general directions to learning behavior" (p. 9). Oxford (1990) defines learning styles as "the general approaches that students use in acquiring a new language or in learning any other subject" (p. 2). According to Reid (1995), "Learning styles are internally based on characteristics of individuals for intake of understanding of new information." Felder (1995) suggests that "the ways in which an individual characteristically acquires, retains and retrieves information are collectively called as individual learning styles" (p. 21).

\section{Learning Styles Models}

\section{Fleiming and Mill's (1984) VARK Model}

Fleiming and Mill's (1984) VARK model of learning consists of visual, auditory, read-write and kinesthetic styles. Visual learners prefer to learn by seeing, auditory learners learn by hearing information, the read-write style has the preference for written explanations and reading, and kinesthetic learners learn by doing things.

\section{Ehrman and Oxford's (1990) Model}

Ehrman and Oxford's (1990) model shows a great dimension of learning styles, such as sensory preferences (visual, auditory, kinesthetic and tactile), personality types (extroverted vs. introverted, intuitive-random vs. sensing-sequential), and global or holistic vs. analytic learners.

\section{Reid's (1987) Perceptual Learning Styles}

Another significant classification has been made by Reid (1987). She first classified learning styles into two groups, such as perceptual and sociological learning style. The inventory made for her study on Russian ESL learners is known as Perceptual Learning Style Preferences Questionnaire (PLSPQ). 


\section{Perceptual Learning Style Preference}

Visual LS Preference: Visual learners learn well when they see information in front of them, e.g. information presented in whiteboard or projectors. They prefer to read instructions and tasks like jotting down points, drawing, reading books, etc. make their learning better.

Auditory LS Preference: Theses learners learn from hearing spoken words and oral explanations. They remember information by reading aloud especially when learning a new material. Hearing audio tapes, lectures, and class discussion benefit these learners to a great extent.

Kinesthetic LS Preference: Those who are kinesthetic learners, learn best by experiencing the situation and being involved physically in classroom activities, by actively participating in field trips and role-playing in the classroom.

Tactile LS Preference: These learners learn best when they have the opportunity to do "hands-on" activities with materials. For example, touching and working with materials, writing notes or instructions, and physical involvement in class related activities, etc.

\section{Sociological Learning Style Preference}

Group vs. Individual LS Preference: Group learners learn more effectively when they study with other students. They prefer group interaction and discussion while individual learners think well when they work alone. Thus, working with a group often makes learning difficult for the individual learners.

Later Reid (1995) categorized LS according to three groups, such as cognitive, sensory, and personality learning style. However, there are several other known models for LS such as Kolb's (1984) LS Inventory, Grasha-Reichmann's (1996) Student's LS Scales, O'Brien's Learning Channel Preference, etc.

\section{Relevant Studies on Learning Style Preferences of ESL/ EFL Learners}

Reid's (1987) study on the Russian ESL students' learning preferences based on her learning style instrument PLSPQ revealed that the ESL learners vary significantly in their sensory preferences. The Asian learners are highly visual, and Koreans are the most visual. Her study also shows that ESL learnersgenerally prefer the kinesthetic and tactile style while group learning is neglected to a large extent. She emphasized the matching of teaching styles with learning styles in the classroom teaching.

Other studies regarding learning styles revealed a high preference for kinesthetic styles of ESL learners. For example, Mulalic et al. (1985) suggested in their study based on Malaysian ESL learners' style preferences that the most noticeable style was the kinesthetic style and learners had a minor preferences for auditory, visual, and group learning. Again, a recent study done by Juris et al. (2009) among Columbian ESL learners has shown a similar result with kinesthetic being the highly preferred styles among ESL students.

In contrast, Wintergerst, DeCapua, and Marylin (2003) have done a research among three kinds of populations, such as Russian ESL, Russian EFL, and Asian ESL learners. The study has shown that the ESL learners have high preferences for group learning. Similarly, Karthigeyan and Nirmala's (2013) very recent study among ESL learners in higher secondary level in India has shown that learners have a very low preferences for kinesthetic styles and high preferences for visual styles. 
Now, in the context of Bangladesh, only little research has been done regarding the learning style preferences of the English language learners. Since in Bangladesh, English is mainly taught as a subject or compulsory course (EFL context), it was seen that teachers are less aware of the individual differences of the students (Islam, 2013) and therefore pay very little attention regarding the same. Islam (2013) went on to explore the Bangladeshi EFL undergraduate students' learning preferences and teachers' awareness regarding it. His study has shown that majority of the students does not prefer to work individually in the classroom which the teachers have not been quite aware of. In contrary, the students and teachers share similar outlook in other cases, such as, they both prefer the visual presentation of information through the use of multimedia and other aids.

A second study on the Bangladeshi EFL learners' learning style preferences has been done by Huda (2013) at the higher secondary level. The study shows a diverse set of style preferences among the EFL students. It shows that they have preferences for reflective learning, Field-dependent and field-independent, auditory and tactile styles. Further, the study shows a huge conflict between learners "e style preferences and teachers' perceptions about the learners' styles. Thus, research on learning styles has provided a different view on learning and teaching in the classrooms in the recent decades.

\section{Methodology}

The aim of this study is to explore whether and to what extent the MA ELT students of the English Department of the University of Dhaka follow language learning styles and what are the most preferred and least preferred styles used by them. This is an exploratory study in which a mixed-method design was followed by using a questionnaire and interview.

\section{Instruments}

Questionnaire: Reid's (1984) 'Perceptual Learning Style Preference Questionnaire' (PLSPQ) was used in this study as a data collection tool. The questionnaire consisted of thirty items of learning style preferences and divided into six different learning styles such as visual, auditory, kinesthetic, tactile, group and individual styles. The items of the questionnaire were designed on a five-point Likert Scale ranging from 'strongly agree' to 'strongly disagree'.

Interview: For collecting the qualitative data for the study, interview of five MA ELT students was taken. The interview was conducted individually on a suitable time for both the researcher and the students.

\section{Sampling}

30 (17 female and 13 male) students of MA Applied Linguistics and ELT, 2nd semester of the academic session 2012-2013 in the Department of English at Dhaka University was selected purposively as the subject of the study. Only 30 students were selected particularly from this batch because of their availability to the researcher.

\section{Methods of Data Collection}

The questionnaire was administered by the researcher at the beginning of a class. Before distributing the questionnaires, the researcher explained the aim and purpose of the survey and requested the participants to respond which they willingly did. Five students from the sample were chosen by the researcher for participating in the interview. The interview was conducted on a suitable time to both. 


\section{Methods of Data Analysis}

The questionnaire was analyzed by using Microsoft Excel. Descriptive statistics (frequencies and means) were calculated for each variable to identify the extent of use of learning styles and the most preferred and least preferred learning styles of the students. On the other hand, the interview responses were tape-recorded and transcribed by the researcher to find out information about their learning styles preferences. It was then analyzed concerning the information about learning styles.

\section{ResUltS AND Discussion OF THE Findings}

Research Question 1: To what extent do the ELT students of English Department at the University of Dhaka follow language learning styles?

\section{Visual Learning Style}

The frequency of ELT students' visual style preference is presented in Table 1 below.

Table 1: Questionnaire Results: Visual Learning Style

\begin{tabular}{|c|c|c|c|c|c|c|c|c|c|c|c|c|}
\hline \multirow{2}{*}{$\dot{z}$} & \multirow{2}{*}{ Statement } & \multicolumn{2}{|r|}{5} & \multicolumn{2}{|r|}{4} & \multicolumn{2}{|r|}{3} & \multicolumn{2}{|r|}{2} & \multicolumn{2}{|c|}{1} & \multirow{2}{*}{$\stackrel{\text { ฐ }}{\Sigma}$} \\
\hline & & $f$ & $\%$ & $f$ & $\%$ & $f$ & $\%$ & $f$ & $\%$ & $f$ & $\%$ & \\
\hline 1 & $\begin{array}{l}\text { I learn better by reading } \\
\text { what the teacher writes } \\
\text { on the board. }\end{array}$ & 7 & 23.33 & 12 & 40 & 5 & 16.67 & 6 & 20 & 0 & 0 & 3.67 \\
\hline 2 & $\begin{array}{l}\text { I highlight the text in } \\
\text { different colors when I } \\
\text { read. }\end{array}$ & 3 & 10 & 17 & 56.67 & 2 & 6.67 & 8 & 26.67 & 0 & 0 & 3.5 \\
\hline 3 & $\begin{array}{l}\text { I understand better } \\
\text { when I read instructions } \\
\text { or information. }\end{array}$ & 3 & 10 & 19 & 63.33 & 2 & 6.67 & 6 & 20 & 0 & 0 & 3.63 \\
\hline 4 & $\begin{array}{l}\text { I learn better by reading } \\
\text { than by listening to } \\
\text { someone. }\end{array}$ & 6 & 20 & 9 & 30 & 2 & 6.67 & 11 & 36.67 & 2 & 6.67 & 3.2 \\
\hline 5 & $\begin{array}{l}\text { I learn more by reading } \\
\text { textbooks than by } \\
\text { listening to lectures. }\end{array}$ & 2 & 6.67 & 9 & 30 & 5 & 16.67 & 12 & 40 & 2 & 6.67 & 2.9 \\
\hline & & & & & & & & Mea & of $\mathrm{Vi}$ & ual & Style & 3.38 \\
\hline
\end{tabular}

5 = Strongly Agree, $4=$ Agree, $3=$ Undecided, $2=$ Disagree, $1=$ Strongly Disagree, $\mathrm{f}=$ Frequency, \%= Percentage

Table 1 reveals the ELT students' frequency of using visual learning styles. The results show that majority of the students $(63.33 \%)$ prefer to learn by reading instructions or information rather than listening to the teacher in the class. More than half of the samples $(56.67 \%)$ highlight texts in different colors because they prefer to see information in front of them. The results also show that $40 \%$ students are almost in disagreement with the previous statement while $16.67 \%$ are uncertain about their visual preference. To learn best, visual learners need to see the information in front of them either written or in numerical form (Herod, 2000, p.6). Hence, they can use visual aids, mapping, diagrams, charts, mapping, films and videos and so on to enhance their own learning. 


\section{Auditory Learning Style}

The extent of ELT students' auditory style preference is presented in Table 2 below.

Table 2: Questionnaire Results: Auditory Learning Style

\begin{tabular}{|c|c|c|c|c|c|c|c|c|c|c|c|c|}
\hline \multirow[b]{2}{*}{$\dot{0}$} & \multirow[t]{2}{*}{ Statement } & \multicolumn{2}{|r|}{5} & \multicolumn{2}{|r|}{4} & \multicolumn{2}{|c|}{3} & \multicolumn{2}{|c|}{2} & \multicolumn{2}{|c|}{1} & \multirow{2}{*}{$\sum_{\Sigma}^{\mathbb{J}}$} \\
\hline & & $f$ & $\%$ & $f$ & $\%$ & $f$ & $\%$ & $f$ & $\%$ & $f$ & $\%$ & \\
\hline 6 & $\begin{array}{l}\text { When the teacher tells me } \\
\text { the instructions I } \\
\text { understand better. }\end{array}$ & 11 & 36.67 & 15 & 50 & 2 & 6.67 & 1 & 3.33 & 1 & 3.33 & 4.13 \\
\hline 7 & $\begin{array}{l}\text { When someone tells me } \\
\text { how to do something in } \\
\text { class, I learn it better. }\end{array}$ & 4 & 13.33 & 17 & 56.67 & 6 & 20 & 2 & 6.67 & 1 & 3.33 & 3.7 \\
\hline 8 & $\begin{array}{l}\text { I remember things I have } \\
\text { heard well than things I } \\
\text { have read. }\end{array}$ & 12 & 40 & 11 & 36.67 & 2 & 6.67 & 3 & 10 & 2 & 6.67 & 3.93 \\
\hline 9 & $\begin{array}{l}\text { I prefer listening to the } \\
\text { lecture in class. }\end{array}$ & 6 & 20 & 18 & 60 & 3 & 10 & 3 & 10 & 0 & 0 & 3.9 \\
\hline 10 & $\begin{array}{l}\text { I learn better in class when } \\
\text { I listen to someone rather } \\
\text { than participate in it. }\end{array}$ & 5 & 16.67 & 15 & 50 & 3 & 10 & 6 & 20 & 1 & 3.33 & 3.57 \\
\hline
\end{tabular}

$5=$ Strongly Agree, 4 = Agree, 3 = Undecided, 2 = Disagree, $1=$ Strongly Disagree, $\mathrm{f}=$ Frequency,$\%=$ Percentage

The results in Table 2 represent the students' auditory style preferences. The majority of the students $(60 \%)$ had a preference for listening to the class lectures. More than fifty-six percent admitted that they learn well when someone tells them the instructions instead of reading on their own. The results also show that very few students $(20 \%)$ had less preference for this style. Thus, those who are auditory learners can use tape lectures, talk aloud when studying, discuss with friends, etc. because these learner learn best when they "use their hearing to learn" (Herod, 2000, p.7).

\section{Kinesthetic Learning Style}

Table 3 reveals the frequency of following kinesthetic learning styles among the ELT students.

Table 3: Questionnaire Results: Kinesthetic Learning Style

\begin{tabular}{|c|c|c|c|c|c|c|c|c|c|c|c|c|}
\hline \multirow{2}{*}{ Z } & \multirow[t]{2}{*}{ Statement } & \multicolumn{2}{|r|}{5} & \multicolumn{2}{|r|}{4} & \multicolumn{2}{|r|}{3} & \multicolumn{2}{|c|}{2} & \multicolumn{2}{|c|}{1} & \multirow{2}{*}{ ᄅँ } \\
\hline & & $f$ & $\%$ & $f$ & $\%$ & $f$ & $\%$ & $f$ & $\%$ & $f$ & $\%$ & \\
\hline 1 & $\begin{array}{l}\text { I prefer to learn by doing } \\
\text { something in class. }\end{array}$ & 5 & 16.67 & 13 & 43.33 & 4 & 13.33 & 7 & 23.33 & 1 & 3.33 & 3.47 \\
\hline 2 & $\begin{array}{l}\text { I concentrate better when I } \\
\text { move around (e.g., pacing or } \\
\text { my tapping feet). }\end{array}$ & 8 & 26.67 & 12 & 40 & 5 & 16.67 & 4 & 13.33 & 1 & 3.33 & 3.73 \\
\hline 3 & $\begin{array}{l}\text { I prefer hands-on activities } \\
\text { to learn better (e.g. } \\
\text { experiments, etc.). }\end{array}$ & 7 & 23.33 & 8 & 26.67 & 10 & 33.33 & 5 & 16.67 & 0 & 0 & 3.57 \\
\hline 4 & $\begin{array}{l}\text { I understand things better in } \\
\text { class when I participate in } \\
\text { role-playing. }\end{array}$ & 5 & 16.67 & 14 & 46.67 & 7 & 23.33 & 2 & 6.67 & 2 & 6.67 & 3.6 \\
\hline 5 & $\begin{array}{l}\text { When I speak, I move my hands } \\
\text { a lot to express myself better. }\end{array}$ & 7 & 23.33 & 17 & 56.67 & 4 & 13.33 & 1 & 3.33 & 1 & 3.33 & 3.93 \\
\hline
\end{tabular}

5 = Strongly Agree, 4 = Agree, 3 = Undecided, 2 = Disagree, 1 = Strongly Disagree, $\mathrm{f}=$ Frequency, $\%=$ Percentage 
Table 3 shows that more than fifty percent of the samples preferred kinesthetic styles. Theses learners make lots of body movements while learning. Similarly, $46.67 \%$ agree that activities like role-playing in class or other physical movements make their learning more effective. Since a majority of the students had a preference for this style, they need to engage themselves in field trips, role-playing, and other hands-on activities to enhance their learning. In contrast, those who did not prefer kinesthetic style need to identify their own predominant learning styles to aid themselves.

\section{Tactile Learning Style}

Table 4 shows the frequency of following tactile learning styles among the ELT students.

Table 4: Questionnaire Results: Tactile Learning Style

\begin{tabular}{|c|c|c|c|c|c|c|c|c|c|c|c|c|}
\hline \multirow{2}{*}{$\dot{\mathrm{z}}$} & \multirow[t]{2}{*}{ Statement } & \multicolumn{2}{|r|}{5} & \multicolumn{2}{|r|}{4} & \multicolumn{2}{|r|}{3} & \multicolumn{2}{|r|}{2} & \multicolumn{2}{|c|}{1} & \multirow{2}{*}{$\sum_{\Sigma}^{\mathbb{\Xi}}$} \\
\hline & & $f$ & $\%$ & $f$ & $\%$ & $f$ & $\%$ & $f$ & $\%$ & $f$ & $\%$ & \\
\hline 1 & $\begin{array}{l}\text { I learn more when I can } \\
\text { make a model or graph of } \\
\text { something. }\end{array}$ & 10 & 33.33 & 11 & 36.67 & 7 & 23.33 & 2 & 6.67 & 0 & 0 & 3.97 \\
\hline 2 & $\begin{array}{l}\text { I learn more when I make } \\
\text { something for a class project } \\
\text { (e.g. posters, flashcards, etc.). }\end{array}$ & 6 & 20 & 14 & 46.67 & 7 & 23.33 & 3 & 10 & 0 & 0 & 3.77 \\
\hline 3 & $\begin{array}{l}\text { I learn better when I make } \\
\text { drawings as I study. }\end{array}$ & 11 & 36.67 & 7 & 23.33 & 5 & 16.67 & 6 & 20 & 1 & 3.33 & 3.7 \\
\hline 4 & $\begin{array}{l}\text { When I build something, I } \\
\text { remember what I have } \\
\text { learned better. }\end{array}$ & 6 & 20 & 14 & 46.67 & 8 & 26.67 & 2 & 6.67 & 0 & 0 & 3.8 \\
\hline 5 & $\begin{array}{l}\text { I usually draw diagrams or } \\
\text { charts of important points } \\
\text { when I study. }\end{array}$ & 1 & 3.33 & 15 & 50 & 3 & 10 & 10 & 33.33 & 1 & 3.33 & 3.17 \\
\hline
\end{tabular}

5 = Strongly Agree, 4 = Agree, $3=$ Undecided, $2=$ Disagree, $1=$ Strongly Disagree, $\mathrm{f}=$ Frequency, $\%=$ Percentage

The results in Table 4 show that half of the students (50\%) use diagrams or charts to understand important ideas. More than forty percent $(46.67 \%)$ agreed that they learn better when they make something on their own for a class project, such as posters, flashcards, etc. In contrast, $26.67 \%$ were unsure whether making drawings about concepts actually helps them learn better, and $33.33 \%$ students mentioned their less preference for this learning style. Those who are tactile learners, hence, can use puzzles and flip cards, sliders, texture posters, mini whiteboard and multi-colored pens to learn better.

\section{Group Learning Style}

The following Table reveals the extent of using group learning styles of the Bangladeshi ELT students. 
Table 5: Questionnaire Results: Group Learning Style

\begin{tabular}{|c|c|c|c|c|c|c|c|c|c|c|c|c|}
\hline \multirow{2}{*}{$\dot{0}$} & \multirow[t]{2}{*}{ Statement } & \multicolumn{2}{|r|}{5} & \multicolumn{2}{|r|}{4} & \multicolumn{2}{|r|}{3} & \multicolumn{2}{|r|}{2} & \multicolumn{2}{|c|}{1} & \multirow{2}{*}{$\sum_{\Sigma}^{\overparen{\Xi}}$} \\
\hline & & $f$ & $\%$ & $f$ & $\%$ & $f$ & $\%$ & $f$ & $\%$ & $f$ & $\%$ & \\
\hline 1 & $\begin{array}{l}\text { I get more work done when I } \\
\text { work with others. }\end{array}$ & 7 & 23.33 & 13 & 43.33 & 4 & 13.33 & 6 & 20 & 0 & 0 & 3.7 \\
\hline 2 & $\begin{array}{l}\text { I like discussion in class and } \\
\text { group projects. }\end{array}$ & 11 & 36.67 & 8 & 26.67 & 4 & 13.33 & 7 & 23.33 & 0 & 0 & 3.77 \\
\hline 3 & $\begin{array}{l}\text { I love to share my ideas with } \\
\text { my classmates. }\end{array}$ & 7 & 23.33 & 14 & 46.67 & 3 & 10 & 5 & 16.67 & 1 & 3.33 & 3.7 \\
\hline 4 & $\begin{array}{l}\text { I enjoy working on an } \\
\text { assignment with two or three } \\
\text { classmates. }\end{array}$ & 7 & 23.33 & 14 & 46.67 & 3 & 10 & 5 & 16.67 & 1 & 3.33 & 3.7 \\
\hline 5 & $\begin{array}{l}\text { I prefer to study with others } \\
\text { because only then I remember } \\
\text { things better. }\end{array}$ & 6 & 20 & 14 & 46.67 & 3 & 10 & 5 & 16.67 & 2 & 6.67 & 3.57 \\
\hline & & & & & & & 2 of & & Lea & & Style & 3.688 \\
\hline
\end{tabular}

$5=$ Strongly Agree, $4=$ Agree, $3=$ Undecided, $2=$ Disagree, $1=$ Strongly Disagree, $\mathrm{f}=$ Frequency, $\%=$ Percentage

The results in Table 5 reveal that less than half of the samples (46.67\%) prefer working in groups while learning something new. They love to share their ideas and opinions with their classmates. The results also show that almost $23.33 \%$ of the students are in disagreement with this statement and prefer to work alone while $13.33 \%$ are quite unsure of this fact. For learners who prefer group styles, it is always better to set them with tasks that needs pair works and group works. On the other hand, those who do not prefer working in groups may face extreme difficulty if are forced to work with groups or has to take part in classroom discussion.

\section{Individual Learning Style}

Table 6 shows the frequency of using individual learning styles of the ELT students.

Table 6: Questionnaire Results: Individual Learning Style

\begin{tabular}{|c|c|c|c|c|c|c|c|c|c|c|c|c|}
\hline \multirow{2}{*}{ Z } & \multirow{2}{*}{ Statement } & \multicolumn{2}{|r|}{5} & \multicolumn{2}{|r|}{4} & \multicolumn{2}{|r|}{3} & \multicolumn{2}{|r|}{2} & \multicolumn{2}{|c|}{1} & \multirow{2}{*}{$\sum_{\Sigma}^{\mathbb{E}}$} \\
\hline & & $f$ & $\%$ & $f$ & $\%$ & $f$ & $\%$ & $f$ & $\%$ & $f$ & $\%$ & \\
\hline 1 & $\begin{array}{l}\text { When I study alone, I } \\
\text { remember things better. }\end{array}$ & 9 & 30 & 9 & 30 & 4 & 13.33 & 5 & 16.67 & 3 & 10 & 3.53 \\
\hline 2 & $\begin{array}{l}\text { I like to think on my own } \\
\text { before listening to others. }\end{array}$ & 8 & 26.67 & 13 & 43.33 & 0 & 0 & 6 & 20 & 3 & 10 & 3.57 \\
\hline 3 & $\begin{array}{l}\text { In class, I work better when I } \\
\text { work alone. }\end{array}$ & 6 & 20 & 8 & 26.67 & 7 & 23.33 & 8 & 26.67 & 1 & 3.33 & 3.33 \\
\hline 4 & $\begin{array}{l}\text { I prefer working on projects } \\
\text { by myself. }\end{array}$ & 4 & 13.33 & 7 & 23.33 & 5 & 16.67 & 11 & 36.67 & 3 & 10 & 2.93 \\
\hline 5 & $\begin{array}{l}\text { I prefer my own ideas when I } \\
\text { solve problems. }\end{array}$ & 5 & 16.67 & 13 & 43.33 & 4 & 13.33 & 6 & 20 & 2 & 6.67 & 3.43 \\
\hline & & & & & & & Mean & & ndivid & 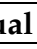 & tyle & 3.358 \\
\hline
\end{tabular}

5 = Strongly Agree, 4 = Agree, $3=$ Undecided, $2=$ Disagree, $1=$ Strongly Disagree, $\mathrm{f}=$ Frequency, $\%=$ Percentage

The results in Table 6 indicate that the ELT students have even less preference for individual style. Only $43.33 \%$ students prefer working individually while $23.33 \%$ are not certain about their individual preference. It also shows that $36.67 \%$ do not prefer this style. 
The results thus indicate that this type of learners prefers to study alone; they have their own individual styles in learning something new or grasping some new information.

From all the Tables it is seen that the ELT students show a major preference for all of the styles. It is important to note that learning styles may overlap and one learner may have several learning styles of which some are of most preferred and some are less. As Oxford (2003) cited Ehrman in her study regarding learning styles, "Learning styles are not dichotomous. Learning styles generally operate on a continuum or on multiple, intersecting continua. For example, a person might be more extraverted than introverted or more closure-oriented than open, or equally visual and auditory but with lesser kinesthetic and tactile involvement" (Ehrman, 1996). So, it is essential for the learners that they identify their own learning preferences and work according to their preferred styles.

Research question 2: What are the most common or preferred as well as least common or least preferred language learning styles of the students?

\section{Most common and least common learning styles preferred by the students}

To answer research question 2 , the researcher has identified the most preferred and least preferred learning styles by the means of the learning styles.

The most common and least common learning style is presented in the Figure below:

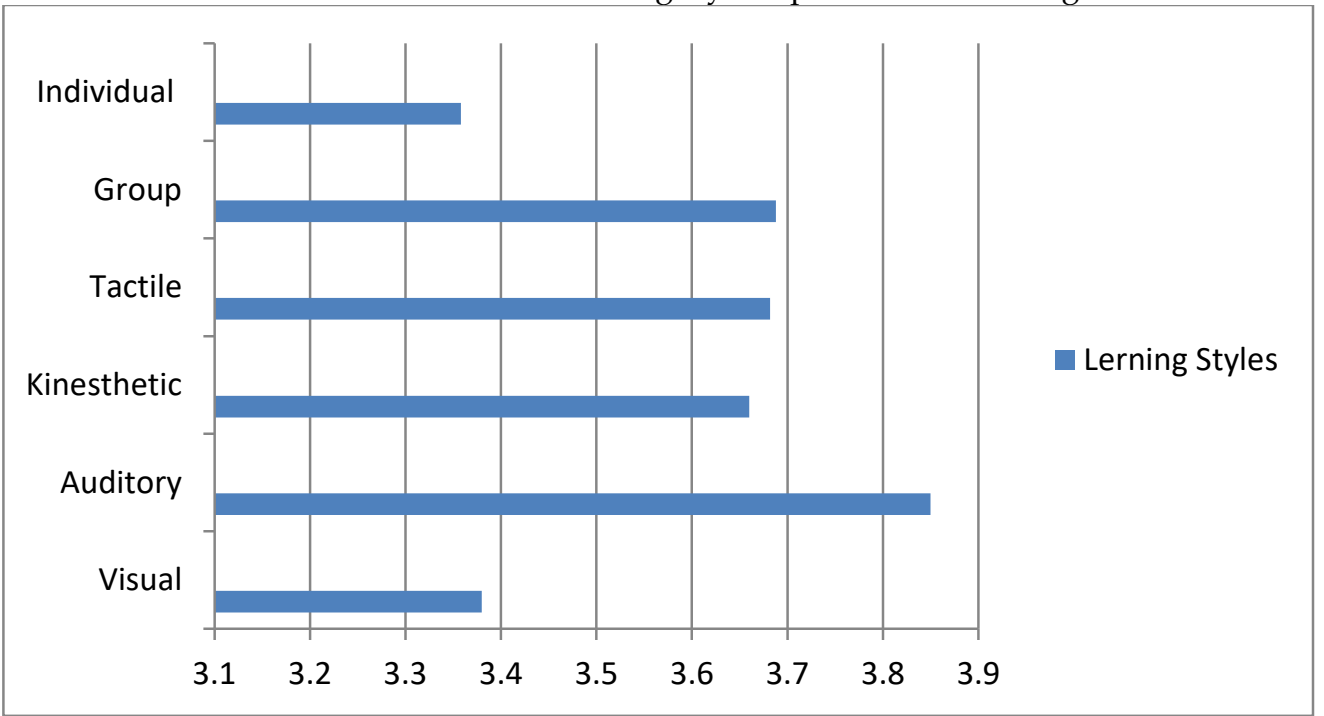

Figure 1: Means of the Learning Styles

Figure 1 indicates that "auditory learning style" has the highest mean $(\mathrm{M}=3.85)$ while 'individual style' has the lowest mean $(M=3.358)$. The results suggest that the majority of these ELT students prefer auditory style which is opposite to Reid's (1987) study where visual style had been the priority among Asians. On the other hand, the students have very low preference for individual learning, rather they prefer working with their classmates or working in groups $(\mathrm{M}=3.688)$ following by tactile $(\mathrm{M}=3.682)$ and kinesthetic styles $(\mathrm{M}=3.67)$. The finding is supported by calculating the means of each learning styles category. The result shows that the most common style of the MA ELT students is the auditory style and the least common is individual learning style. 


\section{Results of the Interview}

Majority of the students" responses to the interview support the quantitative results gathered through questionnaire. At first, they were asked about their perception of own learning styles. It was found that three of the students" thoughts were similar to the answer they gave on the questionnaire. Surprisingly, the other two students" perceptions about their own learning style did not match with their responses to the questionnaire. For example, both of them think themselves as visual learners but they responded in the questionnaire that they learn better by following tactile and group styles. It might be due to the fact that learning style is overlapping and individuals may learn different things in different ways. Then, to the second question, majority of the students admitted that before learning it in MA, they were aware that they learn better with a particular style, for example, by using visual aids or using physical activities like role-playing, etc. while learning, but they did not know it might be affecting their learning. All of them agreed to the third as well as final questions. Identifying one's own learning styles, they think, have a significant implication to learn a second or foreign language because it motivates them and help them become an autonomous learner, and make experience of English language learning even better, easier and interesting. As to the final question, the students agreed that in Bangladesh context where most of the educational institutions have to deal with large classes, it is often impossible to pay attention to diverse learning styles, yet teachers should have a general idea of the students" most preferred styles so that classroom activities can be chosen suitably and appropriately meeting the minimal requirements of the students.

\section{IMPLICATIONS OF THE STUDY}

The findings of the study have several implications for ESL teaching of this group of learners. The results reveal the most preferred styles of the MA ELT students and their awareness regarding learning style. So, identifying learner's own learning style is crucial since it leads them one step further to become more autonomous and assist their own learning in a more fruitful manner. As Moharrer (2012, p.531) in his study cited Marton (1986), "having knowledge of one's learning style is important because it is considered to be an effective approach to guide learners, to make them more oriented towards learning as well as to assist them to manage their own learning according to their educational goals and objectives" (in Pouryahya, 2009, p.5). Wu (2010) also suggested that "ESL teaching should be designed to suit the style preferences of its learners (p. 231)." Hence, the findings of the study suggest that the ELT students, when they become teachers themselves, may become aware of their students" diverse learning styles and follow tasks or activities in the classroom accordingly. Further, the teachers may adapt materials that are suitable for auditory and group learners in the classroom. Again, teachers should assign a variety of tasks to motivate all students because in a large class in the context of Bangladesh, it is almost impossible to pay attention to all the students" preference. In this case, a variety of tasks with a flexible attitude to language learning may enhance and ensure overall students' engagement in learning.

\section{CONCLUSION AND LIMITATIONS OF THE STUdY}

The study explored the ELT students' language learning style preferences based on six perceptual learning styles: visual, auditory, kinesthetic, tactile, group and individual. The findings reveal that the ELT students of the English department have their own learning styles of which some are predominant and some are less and about which they are more or 
less aware of. The findings also show that among the six perceptual learning styles, students follow the auditory styles most and individual style least. Though the auditory style is found to be the predominating one, students have preferences for other styles too. For example, they have shown almost equal preferences for group learning, kinesthetic and tactile styles. Hence, it can be said that learning styles do not work in vacuum and are not dichotomous. One single individual may have preference for several styles because one may prefer to learn different things in many different ways following a wide range of activities. So, discovering students' learning styles in a class, especially in an EFL context like Bangladesh, is equally important as to discovering the teaching styles of the teachers; and if there is a mismatch it should be balanced as much as possible.

But it is not possible to claim that the findings of the study are appropriate for all the ELT students of Bangladesh because the sample size was small and limited to a particular group of learners within a particular university. The other limitation of the study is that it does not show any relationship between teaching styles of the teachers and the learning styles since it was a small scale research, focusing only on exploring the learning styles of the MA ELT students. Another limitation of the study is that interview of only five students were conducted which should not be generalized to all Bangladeshi students. Further, classroom observation would have produced a detailed data and a better picture of how students really accommodate their learning styles with the classroom environment and the teaching styles of the teacher. Despite these limitations, the study is important because it reveals a clear picture of the Dhaka University MA ELT students' own preference for better learning. Further study in this field is needed with a large sample which may include the teachers as well in order to investigate the match or mismatch between both of their styles in the Bangladeshi classroom.

\section{REFERENCES}

Ahmed, H. (2013). "Investigating EFL University Students' Learning Styles", ADAB AL- RAFIDAYN, pp. 66.

Cornett, C. (1983). "What You Should Know About Teaching and Learning Styles",Phi Delta Kappa Educational Foundation, Bloomington, IN.

Felder, R. M., \& Henriques, E. R. (1995). “Learning and Teaching Styles in Foreign and Second Language Education",Foreign Language Annals, Vol. 28 No. 1, pp. 21-31.

Herod, L. (2000). "Learning Styles and Strategies", pp. 3-54, Retrieved August 13, 2014

Huda, M. E. (2013). "Learning Style Preferences of EFL Learners at Higher Secondary Level in Bangladesh", Global Journal of HUMAN SOCIAL SCIENCE, Vol. 13 No. 11, pp. 43-50, doi: 2249$460 x$

Islam, J. (2011). "Language Learning Style Preferences: Bangladeshi EFL Learners",Harvest: Jahangirnagar Studies in Language and Literature, Vol. 26, pp. 1-16.

Juris, M. (2009). "Learning and Teaching Crosswords",Institute for Learning Styles Journal, Vol. 1 (Spring 2009), pp. 1-19, Retrieved from www.auburn.edu

Karthigeyan, K., \& Nirmala, K. (2013). "Learning Style Preference of English Language Learners",Educationia Confab,Vol. 2 No. 1, pp. 134-140, doi: 2320-009X

Kolb, A., \& Kolb, D. (1984). "Kolb Learning Style Inventory",Experiential Learning, pp. 1-4, Englewood Cliffs, NJ: Prentice Hall.

Moharrer, Z. (2012). "A Review on Learning Style Preferences for EFL Language Learners In Online Context",LANGUAGE IN INDIA, Vol. 12 No. 1, pp. 527-548, retrieved from www.languageinindia.com 
Mulalic, A., Shah, P. M., \&Ahmad, F. (1985). “Learning-Style Preference of ESL Students", AJTLHE, Vol. 1 No. 2, pp. 9-17.

Oxford, R. (2003). “Language Learning Styles And Strategies: An Overview”, GALA, pp. 1-25.

Reid, J. M. (1987). "The Learning Style Preferences of ESL Students",TESOL QUARTERLY, Vol. 21 No. 1, pp. 87-111.

Reid, J. (1995). Learning Styles in the ESL/EFL Classroom. Boston: Heinle E Heinle.

Wintergerst, A., DeCapua, A., \& Verna, M. (2003). Conceptualizing Learning Style Modalities for ESL/EFL Students. System,Vol. 31 No. 1, pp. 85-106, retrieved from www.sciencedirect.com

Wu, M. M. (2010). “An Exploratory Study of the Language-learning Style Preferences and Languagelearning Motivation of ESL Learners at a Vocational Education Institute in Hong Kong",Electronic Journal of Foreign Language Teaching, Vol. 7 No. 2, pp. 222-238, retrieved from http:/ /e-flt.nus.edu.sg/ 


\section{APPENDICES}

\section{Appendix 1: Questionnaire \\ Perceptual Learning Style Preference Questionnaire (Copyright 1984, by Joy Reid)}

\section{Directions:}

People learn in many different ways. For example, some people learn primarily with their eyes (visual learners) or with their ears (auditory learners); some people prefer to learn by experience and /or by "hands-on" tasks (kinesthetic or tactile learners); some people learn better when they work alone while others prefer to learn in groups.

This questionnaire has been designed to help you identify the way(s) you learn best - the way(s) you prefer to learn.

Decide whether you agree or disagree with each statement. And then indicate whether you:

Strongly Agree (SA)

Agree (A)

Undecided (U)

Disagree (D)

Strongly Disagree (SD)

Please respond to each statement quickly, without too much thought. Try not to change your responses after you choose them. Please answer all the questions.

\section{Reid's (1984) Perceptual Learning Style Preference Questionnaire}

\begin{tabular}{ll|}
\hline Name: & Roll: \\
Institution: & Department: \\
Class: & Gender: \\
\hline
\end{tabular}

\begin{tabular}{|c|c|c|c|c|c|c|}
\hline & Visual Learners & SA & $\mathbf{A}$ & $\mathbf{U}$ & D & SD \\
\hline 1 & $\begin{array}{l}\text { I learn better by reading what the teacher writes on the } \\
\text { board. }\end{array}$ & & & & & \\
\hline 2 & I highlight the text in different colors when I read. & & & & & \\
\hline 3 & $\begin{array}{l}\text { I understand better when I read instructions or } \\
\text { information. }\end{array}$ & & & & & \\
\hline 4 & I learn better by reading than by listening to someone. & & & & & \\
\hline \multirow[t]{2}{*}{5} & $\begin{array}{l}\text { I learn more by reading textbooks than by listening } \\
\text { lectures. }\end{array}$ & & & & & \\
\hline & Auditory Learners & SA & $\mathbf{A}$ & $\mathbf{U}$ & D & SD \\
\hline 6 & $\begin{array}{l}\text { When the teacher tells me the instructions, I } \\
\text { understand better. }\end{array}$ & & & & & \\
\hline 7 & $\begin{array}{l}\text { When someone tells me how to do something in class, I } \\
\text { learn it better. }\end{array}$ & & & & & \\
\hline 8 & I remember things I have heard well than things I have read. & & & & & \\
\hline 9 & I prefer listening to the lecture in class. & & & & & \\
\hline \multirow[t]{2}{*}{10} & $\begin{array}{l}\text { I learn better in class when I listen to someone rather } \\
\text { than participate in it. }\end{array}$ & & & & & \\
\hline & Kinesthetic Style & SA & $\mathbf{A}$ & $\mathbf{U}$ & D & SD \\
\hline 11 & I prefer to learn by doing something in class. & & & & & \\
\hline 12 & $\begin{array}{l}\text { I concentrate better when I move around (e.g., pacing } \\
\text { or my tapping feet). }\end{array}$ & & & & & \\
\hline
\end{tabular}




\begin{tabular}{|c|c|c|c|c|c|c|}
\hline 13 & $\begin{array}{l}\text { I prefer hands-on activities to learn better (e.g. } \\
\text { experiments, etc.). }\end{array}$ & & & & & \\
\hline 14 & $\begin{array}{l}\text { I understand things better in class when I participate in } \\
\text { role-playing. }\end{array}$ & & & & & \\
\hline \multirow[t]{2}{*}{15} & $\begin{array}{l}\text { When I speak, I move my hands a lot to express myself } \\
\text { better. }\end{array}$ & & & & & \\
\hline & Tactile Learners & SA & $\mathbf{A}$ & $\mathbf{U}$ & $\mathbf{D}$ & SD \\
\hline 16 & $\begin{array}{l}\text { I learn more when I can make a model or graph of } \\
\text { something. }\end{array}$ & & & & & \\
\hline 17 & $\begin{array}{l}\text { I learn more when I make something for a class project } \\
\text { (e.g. posters, flashcards, etc.). }\end{array}$ & & & & & \\
\hline 18 & I learn better when I make drawings as I study. & & & & & \\
\hline 19 & $\begin{array}{l}\text { When I build something, I remember what I have } \\
\text { learned better. }\end{array}$ & & & & & \\
\hline \multirow[t]{2}{*}{20} & $\begin{array}{l}\text { I usually draw diagrams or charts of important points } \\
\text { when I study. }\end{array}$ & & & & & \\
\hline & Group Learners & SA & A & $\mathbf{U}$ & $\mathbf{D}$ & SD \\
\hline 21 & I get more work done when I work with others. & & & & & \\
\hline 22 & I like discussion in class and group projects. & & & & & \\
\hline 23 & I love to share my ideas with my classmates. & & & & & \\
\hline 24 & $\begin{array}{l}\text { I enjoy working on an assignment with two or three } \\
\text { classmates. }\end{array}$ & & & & & \\
\hline \multirow[t]{2}{*}{25} & $\begin{array}{l}\text { I prefer to study with others because only then I } \\
\text { remember things better. }\end{array}$ & & & & & \\
\hline & Individual Learners & SA & A & $\mathbf{U}$ & $\mathbf{D}$ & SD \\
\hline 26 & When I study alone, I remember things better. & & & & & \\
\hline 27 & I like to think on my own before listening to others. & & & & & \\
\hline 28 & In class, I work better when I work alone. & & & & & \\
\hline 29 & I prefer working on projects by myself. & & & & & \\
\hline 30 & I prefer my own ideas when I solve problems. & & & & & \\
\hline
\end{tabular}

\section{Appendix 2: Questions for Interview}

1. What do you think is your preferred learning style?

2. Before learning about the concept of "learning styles" in MA, were you aware of your own learning style or that you learn better in a particular way?

3. Do you think identifying one's own learning style is important? Why?

4. When the classroom activities do not match with one's learning style in a large classroom, do you think it will affect his or her learning of English?

\section{Author Biography}

Rumana Rafique has done her B.A in English Literature and Language from the Department of English, University of Dhaka in 2012 and completed her M.A in Applied Linguistics and ELT from the same in 2013. She is currently working as a Lecturer in the Department of English at Eastern University, Dhaka,

Bangladesh. Previously she worked at BRAC Institute of Languages (BIL), BRAC University as Teaching Assistant. Her research interest includes SLA, action research, educational psychology, sociolinguistics, etc. 